\title{
A „szabad” nukleinsavak jelentősége a noninvazív diagnosztikában
}

\author{
Nagy Bálint dr. ${ }^{1}$ - Csanádi Zoltán dr. $^{2}$ - Póka Róbert dr. ${ }^{3}$ \\ Debreceni Egyetem, Általános Orvostudományi Kar, ${ }^{1}$ Humángenetikai Tanszék, \\ ${ }^{2}$ Kardiológiai Intézet, ${ }^{3}$ Szülészeti és Nőgyógyászati Klinika, Debrecen
}

\begin{abstract}
Napjainkban nagy az érdeklődés a „szabad” nukleinsavak pontos élettani szerepének és klinikai diagnosztikai felhasználásának a meghatározására. A „szabad” nukleinsavak lehetnek DNS-, mRNS-, mikro-RNS- és hosszú nem kódoló RNS- (lncRNNA-) molekulák, amelyek megtalálhatók a testfolyadékokban, így például a szérumban, a nyálban, a könnyben. Az élettani szerepük kiderítése napjainkban is folyik, viszont egyre jelentősebb a diagnosztikai alkalmazhatóságuk. A magzati diagnosztikában a noninvazív módon történő mintavétel után nyert „szabad” DNS-t felhasználva több tesztet forgalomba hoztak, ezek specificitása és szenzitivitása eléri a 99,9\%-ot. A szív- és keringési betegek korai diagnosztizálásában a „szabad” nukleinsavak meghatározása biztató eredményekkel szolgál. Az onkológiában a „folyadékbiopsziával” kapcsolatos közlemények megjelenése a más területen dolgozó egészségügyi szakemberek és a közvélemény figyelmét is felkeltette. Folynak a mikro-RNS szerepének és diagnosztikai alkalmazhatóságának a meghatározásai is. A „szabad” nukleinsavak új generációs szekvenálással történő felhasználására a korai diagnosztikában óriási az érdeklődés, de egyelőre nincs elég klinikai adat a lehetséges tesztek megbízhatóságáról és klinikai hasznosságáról. Orv. Hetil., 2016, 157(48), 1900-1909.
\end{abstract}

Kulcsszavak: „szabad” nukleinsavak, DNS, mRNS, mikro-RNS, folyadékbiopszia, diagnosztika

\section{The importance of "free" nucleic acids in the non-invasive diagnostics}

There is a great interest to determine the physiological role of "free" nucleic acids, and to use them in the clinical diagnostics. These could be DNA, mRNA, microRNA and long non-coding RNA molecules, they are in the body fluids, like serum, tear, saliva, etc. Their exact role in the normal and pathological physiological processes is still in the focus of the research, while their use in the diagnostics is becoming more and more important. The use of "free" DNA in the non-invasive prenatal diagnosis is the first clinical application of the new generation sequencers, these methods are able to reach $99.9 \%$ specificity and sensitivity for the detection of the most common trisomies. There are promising results in their use in the diagnosis and classification of heart and cardiovascular diseases. In oncology the possibility to use the "liquid biopsy" captured the attention of not only researchers and clinicians, but the whole community. There is not enough data until today for the clinical utility and applicability of these methods.

Keywords: "free" nucleic acids, DNA, mRNA, microRNA, liquid biopsy, diagnostics

Nagy, B., Csanádi, Z., Póka, R. [The importance of "free" nucleic acids in the non-invasive diagnostics]. Orv. Hetil., 2016, 157(48), 1900-1909.

(Beérkezett: 2016. szeptember 22.; elfogadva: 2016. október 13.)

\section{Rövidítések}

$\mathrm{AMI}=$ akut myocardialis infarctus; CNA = copy number gain; $\mathrm{CRP}=\mathrm{C}$-reaktív protein; CRT = szívreszinkronizációs terápia; ctDNS = keringő tumor-DNS; DNS = dezoxiribonukleinsav; $\mathrm{EF}=$ ejekciós frakció; HDL = high-density lipoprotein; $\mathrm{LDL}=$ low-density lipoprotein; lncRNA = (long non-coding RNA) hosszú nem kódoló RNS; MPS = (massive parallel sequencing) tömeges paralel szekvenálás; NGS = új generációs szekvenálás; NIPT $=$ (non-invasive prenatal testing) noninvazív magzati szűrés; NPV = negatív prediktív érték; PCR = polimeráz láncreakció; $\mathrm{PF}=$ pitvarfibrilláció; $\mathrm{PPV}=$ pozitív prediktív érték; RNS = ribonukleinsav; SNP = egynukleotidos polimorfizmus; SzE = szívelégtelenség 


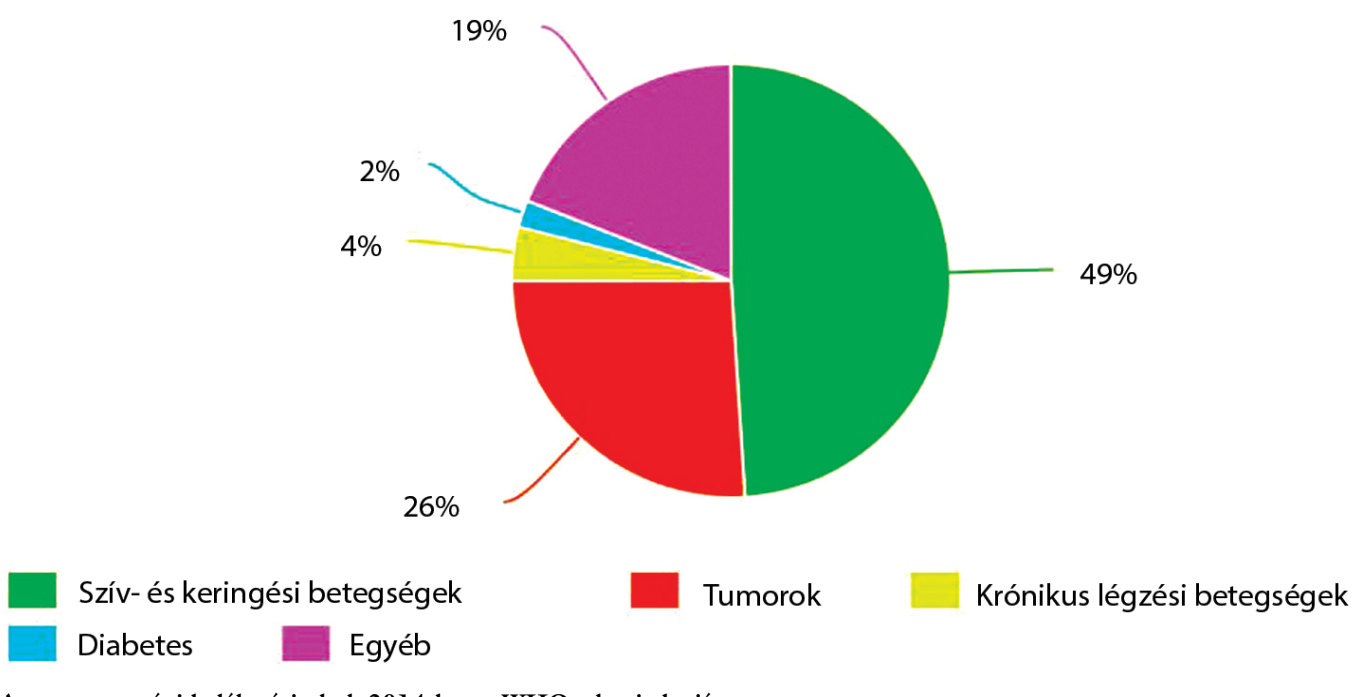

1. ábra $\quad$ A magyarországi halálozási okok 2014-ben a WHO adatai alapján

A magyarországi halálozási statisztikában a szív- és keringési betegségek 49\%-os aránnyal, a tumoros megbetegedések 26\%-kal listavezetők (1. ábra). Az utóbbi időszakban folyamatosan növekszik mindkét megbetegedés száma. A tumoros megbetegedések esetében az új esetek száma a világon 2012-ben elérte a 14 milliót, a halálozások száma a 8,2 milliót. Az új betegek száma várhatóan 70\%-kal fog növekedni a következő két évtizedben (WHO Cancer Reports 2014). Ezek az adatok mutatják, hogy a korai diagnosztikában és a kezelések monitorizálása során is lépéseket kell tenni a rohamosan növekvő számú betegpopuláció korszerű, hatékony ellátására. De az olyan élettani folyamat, mint a várandósság kapcsán végzett genetikai diagnosztikai eljárások is egyre több házaspárt érintenek, főként a késői gyermekvállalás kapcsán mutatkozó gyakoribb genetikai betegségek kimutatása. Erre a molekuláris genetikai eredmények klinikai alkalmazása nyújt kiváló lehetőséget. A „szabad” nukleinsavak felhasználása a diagnosztikában és a terápiában forradalmian új eljárásokat tesz lehetővé. A betegtől egy egyszerü vérvétellel nyert mintából (elegánsan „folyadékbiopszia”) a szérumban vagy a plazmában fellelhető „szabad" nukleinsavakat felhasználva az új genetikai módszerek kiterjesztése óriási jelentőséggel bír.

A naponta százával megjelenő közlemények nyomon követése még a témával foglalkozó szakemberek számára is kihívás, új fogalmak jelennek meg, régi dogmák dőlnek meg egyik pillanatról a másikra. Egyre bonyolultabbak és komplikáltabbak lesznek az élettani múködésekról kapott ismereteink. Összefoglalónkban próbálunk betekintést nyújtani a „szabad” nukleinsavakról és azok felhasználásáról a klinikai gyakorlatban.

\section{A „szabad” nukleinsavak általános jellemzői}

A „szabad” nukleinsavak típusait és méretjellemzőit az 1. táblázatban foglaltuk össze.

\section{„Szabad” DNS}

A „szabad” DNS jelenlétét Mandel és Metais már 1948ban leírták, de felfedezésük sokáig nem keltett különösebb érdeklődést [1]. Tan és mtsai az autoimmun betegségekkel már 1966-ban összefüggésbe hozták, majd később megint a tumorokkal [2]. Leon és mtsai a „szabad" DNS-t 1977-ben elkezdték alkalmazni a tumordiagnosztikában és a kezelésmonitorizálásban, de az utóbbi évtizedig nem történt áttörés ezen a területen [3]. Ellenben Dennis Lo a magzati diagnosztikában sikeresen alkalmazta az anyai vérben 5-10\%-ban jelen lévő „szabad" DNS-t a magzat nemének és $R h D$ vércsoportjának meghatározására a noninvazív módon nyert mintákból már 1997-ben [4]. Az anyai vérkeringésben lévő magzati sejtek és a „szabad” DNS felhasználhatósága párhuzamosan kerültek vizsgálatra. Kezdetben a magzati sejtek és azok alkalmazása az amplifikációs eljárások során tünt a biztatóbb módszernek [5]. Bianchi és munkacsoportja végzett jelentős kutatásokat ezen a területen [6]. Napjainkban a figyelem inkább a „szabad” nukleinsavakra irányul. Nagy volt az érdeklődés a magzati triszómiák kimutatása iránt, ezeket megbízhatóan csak az új generációs szekvenálási módszerek (NGS) biztosítják [7]. Yaron számolt be 2016-ban az irodalomban eddig közölt vizsgálatok számáról, 370348 esetet gyưjtött öszsze tömeges paralel szekvenálással és 27195 esetet kro-

1. táblázat A „szabad” nukleinsavak típusai és méretei

\begin{tabular}{ll}
\hline „Szabad” nukleinsav & Méret \\
\hline DNS & $166 \mathrm{bp}$ \\
mRNS & Változó \\
Mikro-RNS & $18-24 \mathrm{bp}$ \\
Mitokondriális DNS & $>166 \mathrm{bp}$ \\
Hosszú nem kódoló RNS & $<200 \mathrm{bp}$ \\
\hline
\end{tabular}


moszómaspecifikus szekvenálással végzett meghatározásokról [8]. Az NGS a klinikai gyakorlatba a magzati diagnosztika során már bevezetésre került NIPT (noninvasive prenatal testing) néven. Annak ellenére, hogy több százezer mintáról állnak rendelkezésre klinikai adatok és a módszer specificitása, szenzitivitása eléri a 99,9\%ot a 21 . kromoszóma triszómiájának a kimutatására, az NIPT még nem diagnosztika, azaz a pozitív eredményeket a hagyományos invazív módon nyert (amniocentesis, méhlepény-biopszia) minták karyotypizálásával meg kell erősíteni, mert még mindig ez az arany standard módszer. A különböző teszteket forgalmazó cégek által megadott magas specificitás és szenzitivitás félrevezetheti még a szakembereket is, a pozitív prediktív érték (PPV) és a negatív prediktív érték (NPV) több információt szolgáltatnak. Az előbbi annak a valószínúségét fejezi ki, hogy egy pozitív szürési teszttel rendelkező személy valóban beteg, az utóbbi pedig azt, hogy a negatív szűrési teszttel rendelkező személy nem beteg [9].

A betegek szérumában megjelenő tumoreredetű „szabad" DNS rendkívüli lehetőséget biztosít a tumorspecifikus mutációk és egyéb genetikai eltérések kimutatására és a kezelés nyomon követésére. DNS-metilációs eltéréseket és víruseredetú nukleinsavakat is ki lehet mutatni különböző tumorokban [10]. Napjainkban különböző PCR-alapú módszereket alkalmaznak a mikroszatelliták és a jellemző mutációk detektálására [11]. Ezeknél érzékenyebb és pontosabb meghatározásokat biztosít a tömeges paralel szekvenálás (MPS) új biomarkerek kimutatásának a lehetőségével, de a teljes genom is lefedhető [12].

\section{„Szabad” mRNS}

Az emberi genomban körülbelül 25000 gén található, amelyek ha aktívak, bekapcsolt állapotba kerülnek, mRNS íródik át róluk. A különböző szövetek egyedi mRNS-profillal rendelkeznek, ezek a szérumba is kikerülnek, ahonnan kimutatható a jelenlétük. Várandósság során placentaspecifikus markerek mutatkoznak, amelyek alkalmasak lehetnek a diagnosztikában. Az egyik ilyen lehetőség az egynukleotidos polimorfizmus (single nucleotide polymorphism - SNP) felhasználása, az egyes allélok aránya mutatja, hogy hány kópiában van jelen az adott allél, $1: 1$ arány diallélikus, $1: 2$ vagy $2: 1$ arány triszómiás magzatot jelez [13].

A keringésbe kerülő mRNS, meglepő módon, stabil és kimutatható a szérumból vagy plazmából, annak ellenére, hogy magas az RNáz-aktivitás. Ezt az exoszómákba és microvesiculomokba való csomagolással éri el a szervezet [14].

\section{„Szabad” mikro-RNS}

A mikro-RNS-ek a nem kódoló RNS-molekulák csoportjába tartozó 19-25 bázispár hosszú molekulák, ame- lyek hosszabb, 70-100 nukleotidból álló prekurzorokból keletkeznek. Jelentôs részük a kromoszómák törékeny részén kódolódik, amely régióknak jelentős szerepe van a DNS-amplifikációkban, -deletiókban és -transzlokációkban a tumorok fejlődése során.

A mikro-RNS felfedezése az RNS-interferencia leírásával kezdődött 1990-ben petúniáknál. Később Fire és mtsai elvégezték az első kísérleteiket C. elegans-nál és leírták a kis interferáló RNS-t 1998-ban, amiért nyolc évvel később Nobel-díjjal tüntették ki óket [15, 16]. Csak jóval később, 2010-ben derült ki, hogy a szöveteken kívül a mikro-RNS jelen van a különböző testfolyadékokban is, így a vérben, székletben, nyálban, tejben [17]. A mikro-RNS keletkezhet passzívan necrosis és fertőzések következtében, vagy aktív módon az extracelluláris részecskék és makromolekula-komplexekben (Ago, LDL, HDL) történő kiválasztásukkal [18].

Az egyes betegségekben mért mikro-RNS-koncentrációk sokszor ellentétesek, ennek az oka a standardizált kimutatási módszerek hiánya [19].

\section{A „szabad” nukleinsavak klinikai alkalmazhatósága}

\section{Praenatalis magzati diagnosztika}

\section{Magzati „szabad” DNS}

A legegyszerúbb lehetőségnek a kezdetekben a szérumból vagy a plazmából izolált „szabad” nukleinsavak méretmeghatározása tûnt, mivel a magzati „szabad” DNS-t rövidebbnek határozták meg. Ezzel kapcsolatban sok ellentmondó közlemény jelent meg, amely számos félreértésre adott okot. Ezek az ellentmondások fóként technikai okokra vezethetők vissza, a módszerek fejlődése, az eljárások standardizálása segített a régebbi megfigyelések megmagyarázásában.

Az anyáktól noninvazív módon levett mintákból már a kezdeti munkák kimutatták, hogy a magzati "szabad” DNS rövidebb az anyainál, ez a különbség első rátekintésre elég nagynak tünt (>200 bp vs. >1000 bp), de nem volt alkalmazható a klinikai diagnosztikában [20]. Gélelektroforézist, majd ezt követően a kvantitatív PCR-t használtak a méretek meghatározására, sok ellentmondással tarkítva [21]. A pontosabb méretmeghatározást csak a tömeges paralel szekvenálás (MPS) tette lehetővé, ami alapján meghatározták, hogy az anyai plazmából izolált DNS-ból egy 166 bp és egy 143 bp nagyságú lényeges fragmentum mutatható ki, de ezek után vannak kisebb csúcsok is 10 bp különbségekkel [22]. Ezek alapján azt feltételezik, hogy az anyai eredetú fragmentum esetén létezik egy becsomagolt nukleoszómaegység (146 bp) és egy kapcsoló fragmentrégió (20 bp), magzati DNS-nél ez a kapcsoló fragment hiányzik. A 10 bp különbséggel mutatkozó kisebb fragmentumok azon dinukleotid ismétlődő egységekből eredhetnek, amelyek a hisztonokkal vannak kapcsolatban [23]. 


\section{Tumoreredetü „szabad” DNS}

Ellentmondóak az adatok a tumoreredetú DNS-fragmentumok méretével kapcsolatban is, a tumor típusától függően különböző méretű́nek határozták meg. A kezdeti kvantitatív PCR-en alapuló tanulmányok azt sugallták, ezek hosszabbak, később viszont rövidebbnek találták őket [24]. A tömeges paralel szekvenálás lehetőséget biztosított ezen ellentmondás feloldására, Jiang és mtsai tanulmányozták a fragmentumok méretét hepatocellularis carcinomában [25]. Ezeknél a betegeknél is a várandós nők szérumában kimutatott 166 bp nagyságú csúcs volt a legnagyobb mértékben megjelenő a szérumból izolált DNS-ben, ami az apoptózissal történő keletkezésre utal. A fragmentumok méretprofilja viszont azt mutatja, hogy a kisebbek tartalmazzák a tumorra specifikus kópiaszámvesztéseket és -felszaporodásokat (copy number gains - CNA). A hosszabb fragmentumok megjelenése, amelyek kisebb mértékben mutathatók ki, a necrosissal hozhatók összefüggésbe, ezek viszont nem tartalmazzák a tumorral kapcsolatos kópiaszám-eltéréseket [25]. Ez a megfigyelés arra hívta fel a figyelmet, hogy a kisebb frakcióra kell koncentrálni, és a kezelés folyamatát is az ebben a mérettartományban megfigyelhető változások alapján lehet jól monitorozni.

\section{Mitokondriális DNS}

A sejtmageredetú DNS-sel ellentétben a mitokondriális DNS vizsgálata során nem a nukleoszómákra jellemző 166 bp nagyságú fragmentum a jellemző, hanem a rövidebbek. Ez azzal magyarázható, hogy nincsenek hisztonok a mitokondriális DNS-en, amelyek védelmet biztosítanak az enzimatikus lebontással szemben. Ennek a DNS-fajtának a koncentrációja tumoros betegek estében lényegesen magasabbnak bizonyult [25].

\section{A miRNS}

A mikro-RNS mérete 18-24 bp között változik, a génregulációban van fontos szerepük. Az utóbbi idóben kerültek a tanulmányok középpontjába. A leggyakoribb triszómiák kimutatására is történtek próbálkozások miRNS felhasználásával, de az NGS-alapú módszerek megbízhatósága miatt kisebb az érdeklődés ezekre. Viszont vannak jóval gyakoribb, a várandósság kapcsán jelentkező betegségek, mint a gesztációs diabetes, a praeeclampsia és a congenitalis szívbetegségek, ahol még nagyobb jelentőségük lehet.

A gesztációs diabetes a várandósok 6-8\%-ában jelentkezik, a betegség kimutatása a 26-28. terhességi héten végzett glükóztolerancia-teszten alapul a rutin terhességi ellátás során. A kezelés korai megkezdése megelőzheti a szövődmények kialakulását. Erre alkalmasak a miRNSmolekulák, amelyek anyai vérből már a 12 . héten kimutatók, például a miR-16, miR-17, miR-19a, miR-19b és miR-20 [26].

A praeeclampsia a várandósok 3-5\%-ában mutatkozik, eddig nem sikerült olyan biomarkert találni, amely megbízhatóan előre jelezné a súlyos kórkép kialakulását.
A miR-146a-5p, a miR-199a-5p és a miR-22l-3p mutat alacsonyabb expressziót és összefüggést a kórkép kialakulásával [27]. További vizsgálatok szükségesek az alkalmazhatóság pontos megállapítására.

A várandósok $1 \%$-ában jelentkeznek a congenitalis szívbetegségek, ezek kimutatása jelenleg ultrahangvizsgálaton alapul, azonban a korai diagnosztikában, akár már a 12. héttól erre alkalmasnak túnnek a miR-99a, let$7 c$, miR-152b-2, miR-155 és miR-802 [28].

\section{Hosszú nem kódoló RNS}

A hosszú nem kódoló RNS-ek (long non-coding RNA - lncRNA) 200 bp-nál hosszabb fehérjét nem kódoló nukleinsav-molekulák, a gének közötti és az intronok közötti régiókban vagy az adott gén szensz és antiszensz száláról íródnak át [29]. A sejten belül a nucleusban és a kromatinban helyezkednek el, de a szérumba is kikerülnek. Az élettani szerepük az átírás utáni szabályozásban, valamint a telomer replikációjában, RNS-interferenciában van [30].

\section{A diagnosztikai alkalmazhatóság jelenlegi helyzete}

\section{Magzati diagnosztika}

A jelenlegi magzati diagnosztika Magyarországon fóként az államilag finanszírozott invazív mintavételek (méhlepény, magzatvíz) során nyert minták karyotypizálásán alapul. Ez az elfogadott, arany standard módszer. Az utóbbi években a noninvazív módon nyert mintákból, tehát anyai vérből izolált DNS felhasználásával az új generációs szekvenáláson alapuló módszerek felhasználásával történik a leggyakoribb triszómiák kimutatása. A várandósok azonban saját maguk fizetik ki az árát ennek a vizsgálatnak az erre szakosodott magánvállalkozásoknak. A módszerrel kapott pozitív eredményeket minden esetben a hagyományos módszerrel meg kell erősíteni.

Az anyai plazmából nyert „szabad” DNS, amely az anyainak 5-10\%-a, tömeges paralel szekvenáláson alapuló módszerrel 99,9\%-os biztonsággal ki tudja mutatni a Down-szindrómát, de a 18-as és a 13-as kromoszóma triszómiáját is hasonló pontossággal. A téves pozitív eredmények $0,5 \%$ alatt vannak $[31,32]$. A legutóbbi eredmények alapján a módszer már alkalmas a magzati $\mathrm{RhD}$ vércsoport, a génmutációk, a nemikromoszómarendellenességek, microdeletiók, mikroduplikációk és egyéb kromoszómaeltérések kimutatására is [33]. A Magyar Humángenetikai Társaság állásfoglalását már 2014ben megfogalmazta az eljárással kapcsolatban, a többi nemzetközi genetikai társasághoz hasonlóan. Jelenleg tesztként és nem diagnosztikai módszerként javasolja a vizsgálat eredményének az elfogadását. A módszerről történő tájékoztatás és az eredmény kiadása genetikai tanácsadáson keresztül kell, hogy történjen. A módszer előnyei kétség kívül, hogy noninvazív mintavételen alapul, csökkenti az invazív beavatkozások számát, nagyon 
gyors, egy héten belül elkészül az eredmény. Alkalmas a családon belül lévő mutációk kimutatására is. Lehetséges olyan minor kromoszóma-rendellenességek kimutatása, amelyek hagyományos karyotypizálással nem lehetségesek. Arra azonban fel kell hívni a figyelmet, hogy a különböző cégek által forgalmazott NIPT-termékek nem egyformák, különböző a kimutatási alapjuk és nem egyformák a kimutatási lehetőségeik.

\section{Szív-és keringési betegségek}

\section{Akut myocardialis infarctus}

$\mathrm{Az}$ akut myocardialis infarctus ( $A M I)$ diagnosztikájában a troponinmeghatározás terjedt el. Újabb vizsgálatok szerint legalább 20 mikro-RNS szintje mutat összefüggést az AMI-val és ezekból legalább 9 a troponinszintekkel [34]. A $m i R-1, m i R-133, m i R-208$ és a $m i R 499$ a legjobban tanulmányozott molekulák koszorúér-betegségekben és akut myocardialis infarctusban [35]. A sérült myocardiumból kiáramló mikro-RNS-ek mellett az akut esemény után emelkedett szintet mutató miRNS-ek részben extracardialis eredetúek, mint például a $m i R$ $30 c$, miR-145, amelyek ugyanakkor összefüggést mutattak az infarktus méretével. Emellett találtak 20 olyan mikro-RNS-t, amelyek nagyfokú specificitással és szenzitivitással előre jelzik a MI-t [36]. Több tanulmány a miR-208 és miR-499 szintjeit vizsgálta, használhatóságukat a klinikai rutinban nagyobb betegszámon alapuló elemzések alapján lehet megítélni $[37,38]$.

\section{Szívelégtelenség}

A szivelégtelenség ( $S z E$ ) laboratóriumi diagnosztikájában jelenleg a legtöbb segítséget és információt az N-terminal pro-B-type natriuretic peptide (NT-proBNP) szintjének meghatározása jelenti. A szívelégtelenségen belüli két entitás, a megtartott bal kamrai ejekciós frakcióval $(\mathrm{EF})$ járó $\mathrm{SzE}$ (heart failure with preserved $\mathrm{EF}$ : $\mathrm{HF}_{\text {pef }}$ ) és a csökkent EF-fel járó (heart failure with reduced EF: $\mathrm{HF}_{\mathrm{ref}}$ ) elkülönítése képalkotó eljárások nélkül nehézséget jelent, mivel e két SzE-entitás klinikai tünetei hasonlóak és az NT-proBNP-szint alapján sem lehet differenciálni a kettő között. A miRNS-ek diagnosztikus használhatóságáról $\mathrm{HF}_{\text {pef }}$ és $\mathrm{HF}_{\text {ref }}$, valamint nem szívelégtelen betegek kohorszaiban a közelmúltban számoltak be [39]. Öt miRNS-t találtak, amelyek potenciálisan használhatónak tüntek mind a nem szívelégtelen versus SzE-ben szenvedő betegek, mind a $\mathrm{HF}_{\mathrm{pef}}{ }^{-}$és $\mathrm{HF}_{\text {ref }}$-entitások elkülönítésében: $m i R N S-30 c,-146 a,-221,-328$ és -375. Az öt miRNS közül bármelyik kettő az NT-proBNP-vel együtt szignifikánsan javította a diagnosztikus modell pontosságát a csak BNP-meghatározáshoz képest.

A szipreszinkronizációs pacemakerterápia bevezetése a szívelégtelen betegek kezelésében az egyik legfontosabb előrelépést jelentette az utóbbi 20 évben. Az optimális betegkiválasztás számos szempontját sikerült azonosítani, köztük olyan pozitívválasz-prediktorokat, mint a tí- pusos bal-Tawara-szár-blokk-mintázat, a minél szélesebb (>150 ms) QRS-szélesség, a nem ischaemiás szivelégtelenség etiológiája és a női nem [40]. Igazolódott, hogy a szívelégtelen betegek prognózisának felmérésére kifejlesztett Seattle Heart Failure Model a reszinkronizált betegeken is használható [41]. Mindezek ellenére az ajánlásoknak megfelelő betegkiválasztás mellett sem alakul ki a várt terápiás hatás a betegek mintegy 20-40\%ában. Szükség van tehát további prediktív markerek azonosítására, amelyek használatával ez a szám lejjebb szorítható.

Egy közelmúltban megjelent tanulmány a miRNS-ek használhatóságát vizsgálta a reszinkronizáció hatásának előrejelzésében [42]. Első lépésben 6-6 CRT-kezelés után reszponder és nonreszponder betegen elemezték 766 különböző miRNS plazmaszintjének összefüggését a terápiás válasszal. Négy olyan miRNS-t (miR-409-3p, miR-30d, miR-99b és miR-766) találtak, amely korrelált a reszponderitással. Ezt a 4 miRNS-t a továbbiakban prospektíven vizsgálták további 40 betegen, akiket legalább hat hónapig követtek a reszinkronizáció hatásának felmérésére, valamint egészséges (nem szívelégtelen) kontrollegyénekben. A reszponderitás kritériuma a kiindulásihoz képest legalább 10\%-os bal kamrai ejekciósfrakció-növekedés volt. Többváltozós lineáris statisztikai modellezéssel végül a reszponderitás legjobb prediktorának a terápia előtt emelkedett miR-30d-plazmaszintet találták. Reszponder betegeken a $m i R-30 d$ plazmaszintje hat hónappal a reszinkronizációs kezelés után csökkent, míg a terápiarefrakter esetekben szignifikánsan nem változott. További fontos megfigyelés volt, hogy a miR-30d plazmakoncentrációja a sinus coronariusban 18-szoros volt a perifériás mintához képest, ami a szívizomsejtekből történő felszabadulásra utal, feltételezések szerint a mechanikai stressznek kitett területről. A miRd30 magas kiindulási értéke eszerint a súlyos aszinkrónia jele, csökkenése pedig a sikeres reszinkronizációs hatásra, következményesen a myocardiumstressz megszünésére utal.

\section{Pitvarfibrilláció}

A pitvarfibrilláció (PF) a teljes népességen belüli 1-2\%-os előfordulásával szintén korunk egyik cardiovascularis pandémiája. A betegséghez társuló magas morbiditás, mortalitás és az egészségügyi ellátórendszerre rótt terhek indokolják azokat a nagyon jelentős erőfeszítéseket, amelyeket alapkutatók és klinikusok a mechanizmus megértése, a mielőbbi felismerés és hatékonyabb gyógyítás, a szövődmények megelőzése érdekében tesznek. Ez utóbbiak közül a legsúlyosabb következmény a PF-hez társuló stroke, ami megfelelő alvadásgátló kezeléssel többnyire megelőzhető lenne. Ezért is jelent különösen nagy problémát, hogy az esetek pontosan nem ismert, de bizonnyal jelentékeny hányadában a PF tünetmentessége miatt észrevétlen (néma) marad, és az első tünet a következményes stroke. Ez különösen igaz a ritmuszavar 
paroxysmalis formáira, hiszen ilyenkor még az EKGvizsgálat is megtévesztő (negatív) eredményt adhat, ha éppen nem zajló PF alatt készül. Bármely egyszerü vérvizsgálattal kimutatható eltérés, ami PF előfordulására utal, éppen ezért fontos segítséget jelentene azoknak a kiválasztásában, akiknél fokozott erőfeszítés, tartós monitorozási technikák (Holter-vizsgálatok, transztelefonos EKG, implantálható aritmiamonitor) használata indokolt a PF dokumentálására. Liu és mtsai [43] aritmiamentes, paroxysmalis és perzisztens pitvarfibrilláló betegeken végzett miRNS-vizsgálatok során a $m i$ RNS-150 szintjét PF-ben jelentősen alacsonyabbnak mérték, paroxysmalis csoportban 1/17-nek, a perzisztáló betegek között 1/20-nak a kontrollokhoz képest, és fordított arányban korreláltak a CRP-értékekkel. Egy másik vizsgálat [44] amellett, hogy megerősítette a miRNS-150-nel kapcsolatban leírtakat, szintén csökkent expressziót mutatott ki a miRNS-21 vonatkozásában. A PF miatt végzett katéterablatiót követően mindkét miRNS szintje a kiindulási érték háromszorosára emelkedett.

\section{Szívfejlődési rendellenességek}

A hosszú nem kódoló RNS alkalmazásának az egyik érdekes lehetősége a szív- és keringési betegségek. Számos közlemény mutatta ki az elmúlt években, hogy az lncRNA fontos szerepet tölt be a szív fejlődésében. Ilyen például a Braveheart (Bvht), amely felülexpresszált a szívben, de nem kódol fehérjét, viszont hatással van a MESPI-re, amely fontos differenciálódási faktor, embrionális őssejtekből szívizomsejteket képez [45]. Másik hasonló molekula a Fendrr, amely az átírási hálózathoz szükséges, a hisztonmódosító komplexekkel lép kapcsolatba, deletiója kamrai elváltozásokat okoz [46]. Legújabban három lncRNA-t írtak le, amelyek az embrionális őssejtekből az endothelsejtek fejlődését segítik elő, ezek a TERMINATOR, ALIEN és PUNISHER [47]. De más cardiovascularis betegség modellezésekor megtalálták e molekulák szerepét [48]. Például a $C A R L$, amely szívapoptózissal hozható összefüggésbe, kap-

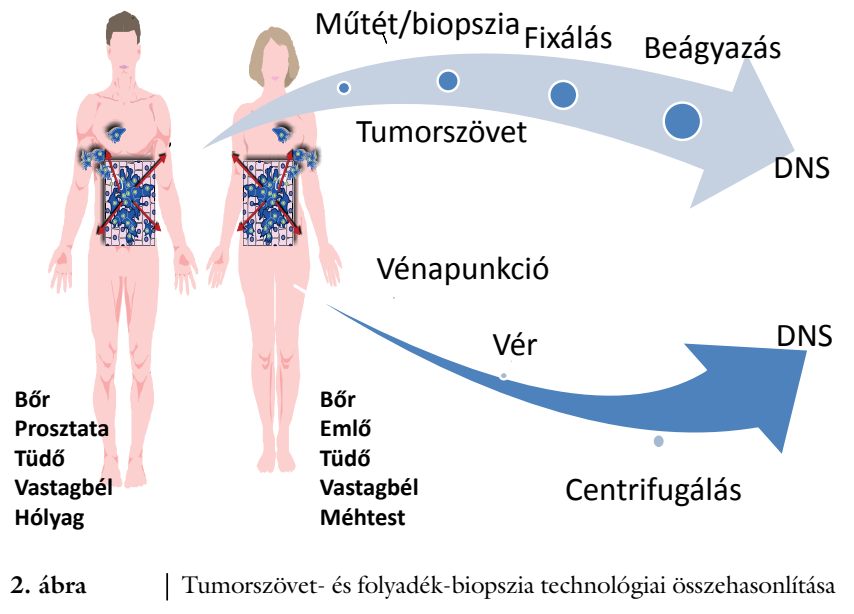

csolódik a miR-539-hez, amely gátolja annak hatását a mitokondriumhasadásra, hasonló hatású az lncRNA $M D R L$, amely a $m i R-361$-et alulszabályozza [49].

\section{Tumordiagnosztika}

A tumorok diagnosztikája bonyolultabb, és kevés adat áll rendelkezésre a „folyadékbiopsziával” nyert minták feldolgozása során kapott eredményekrôl és klinikai tapasztalatokról. Az NIPT-vel elért 99,9\%-os specificitástól és szenzitivitástól még nagyon messze vagyunk a tumordiagnosztika területén. A tumorok hagyományos invazív eljárással történő szövettani és molekuláris diagnosztikai vizsgálata a standard elfogadott diagnosztikai eljárás napjainkban. Ez lehetőséget nyújt olyan genotipizálások elvégzésére is, amelyek segítik a célzott terápia kiválasztását. Az elmúlt években a „folyadékbiopszia” nagy reményeket nyújt a cirkuláló tumor-DNS- (ctDNS-) molekulák felhasználásával a korai tumordiagnosztika és terápia felállításához. Ezek a nukleinsavak az apoptotizáló tumorsejtekből és a keringő tumorsejtekből származnak $[3,11,12]$.

A 2. ábra az invazív mútétek során és a noninvazív „folyadékbiopsziával” nyert minta feldolgozási eljárásait hasonlítja össze, mutatva azt is, hogy melyek a leggyakoribb daganatok a férfiaknál és a nóknél. A mútét alkalmával eltávolított tumor szövettani és molekuláris diagnosztikai vizsgálaton megy keresztül, ami hosszadalmas, nem reprezentálja a szervezetben megtalálható összes daganatot. Ellenben a vérben keringő DNS segítségével feltérképezhető a daganatok összes árulkodó jele, amely a teljes szervezetben mutatkozik, nem csak az eltávolított tumorszövetben. Kimutatható, hogy mely DNSszakaszok fordulnak elő a vártnál magasabb vagy alacsonyabb arányban, vagy milyen mutációk találhatók meg. Noha jelenleg a tumorok hagyományos invazív eljárással történő szövettani és molekuláris diagnosztikai vizsgálata az elfogadott eljárás, számolni kell azzal, hogy amikor már elegendő adat áll rendelkezésre a noninvazív módon nyert minták feldolgozásáról, ez változni fog.

A ctDNS a tumorsejtekból jut a vérbe és az eredeti tumor mutációit tartalmazza. Az új generációs szekvenálók kifejlesztésével napjainkban lehetőség nyílik a genetikai eltérések specifikus és érzékeny kimutatására a noninvazív módon vett mintákból. Ez a jelenlegi tumordiagnosztikát jelentősen segítheti, lehetőséget nyújthat a tumor korai kimutatására, a prognózis és a kezelés meghatározására. Lehetőséget ad a személyre szabott gyógyítás bevezetésére.

A tumorok genotipizálása nagyon fontossá vált a kezelések során, fóként az immunoterápia alkalmazásakor. A klinikai gyakorlatban a genotipizálás szöveti biopsziákból történik, ez a minta azonban nem alkalmas a tumor heterogenitásának és állandó változásainak valós idejü monitorizálására, erre jobban megfelel a vérból izolált ctDNS. Számos tanulmány bizonyította, hogy a ctDNS gyorsan képes előre jelezni a terápia kimenetelét, és fon- 
tos információt nyújt a klinikusnak a következő kezelések megtervezéséhez [12].

Súlyos probléma a terápiarezisztencia kialakulása, amely a kezelések sikertelenségének a legfóbb oka. A legújabb eredmények felhívják a figyelmet arra, hogy a folyadékbiopsziával nyert minták felhasználásával a tumorrezisztencia jóval korábban jelezhető.

A folyadékbiopsziával nyert mintákból izolált ctDNS lehetőséget nyújthat a jövőben a tumorok korai diagnosztizálásához és a genotipizálások eredményeinek felhasználásával a kezelések hatékonyabbá tételéhez, a kezelés hatékonyságának a monitorizálásához, a személyre szabott terápia bevezetéséhez.

A 2. táblázat mutatja a „szabad” DNS alkalmazhatóságát a különböző tumorok diagnosztikájában és a prognózis megállapításában. Látható, hogy hol alkalmas a metiláció, a DNS-integritás, a mikroszatellita-eltérés, vírus-DNS jelenléte és a mitokondriális DNS markerként. A módszer elterjedéséhez és elfogadtatásához szükséges a ctDNS keletkezésének, a sejtekből történő kibocsátás és véráramba kerülés biológiájának a jobb és pontosabb megismerése. Napjainkban még kevés adat áll rendelkezésre a klinikai és analitikai validitásról, továbbá a klinikai hasznosságról.

\section{Patogenezis és diagnosztika}

A humán genom 76\%-a fehérjét nem kódoló, 200 bázispárt meghaladó méretû RNS-szakaszokban íródik át (long non-coding RNA - lncRNA) [50]. 2003-ban Rangel és mtsai írták le első ízben egy petefészekrákra specifikus (human ovarian cancer specific transcript-2 HOST-2), a 10-es kromoszómához köthető 2,9kb méretü RNS-t, amely nem rendelkezik olvasási kerettel és fehérjét sem kódol [51]. A HOST-2-expresszió gátlása a petefészekrákból izolált OVCAR-3 sejtvonal migrációját, proliferációját és invázióját egyaránt gátolta. Ennek a mechanizmusa máig sem tisztázott, de egy közelmúltbeli vizsgálat szerint a HOST-2 molekuláris szivacsként köti a let-7b miRNS-t, s ezáltal gátolja annak múködését. A let-7b miRNS-rôl már korábban ismert volt, hogy a HMGA2, c-myc, Dicer és Imp3 onkogének expresszióját gátolja, így a let-7b szintjének csökkenése fokozza azok expresszióját [52]. A fehérjét nem kódoló RNS-ek a templátként szolgáló DNS elhelyezkedése szerint nemcsak intronokban, hanem exonokban és akár ezek antiszensz szálán is képződhetnek. Ennek egyik példája a HOX transzkripciós antiszensz RNS (HOTAIR). A 6232 bp méretű lncRNA 12-es kromoszóma q13.13 szakaszán képződik. A HOX géncsalád C tagjának transzkriptumaként a $H 3$ hiszton metilációját idézi elö, s ezáltal a 2-es kromoszómán elhelyezkedő HOXD gén epigenetikus blokkolását eredményezi [53]. Epithelialis petefészekrákban a HOTAIR expressziója jelentősen emelkedett, és a tumorprogresszióban kifejtett hatása az apoptózisban szerepet játszó gének ( cyclin E, BCL-2, caspase-9, caspase-3 és BRCAI) szabályozásán keresztül ér-
2. táblázat | A különböző tumorok és a „szabad” DNS felhasználhatósága a diagnosztikában és a prognózisban

\begin{tabular}{|c|c|c|c|}
\hline Tumor & „Szabad” DNS & $\begin{array}{l}\text { Diagnosztikus } \\
\text { marker }\end{array}$ & $\begin{array}{c}\text { Prognosztikus } \\
\text { marker }\end{array}$ \\
\hline \multirow[t]{2}{*}{ Cervix } & Metiláció & $\sqrt{ }$ & $\sqrt{ }$ \\
\hline & Vírus-DNS & $\sqrt{ }$ & \\
\hline \multirow[t]{3}{*}{ Colorectalis } & Mutáció & $\sqrt{ }$ & $\sqrt{ }$ \\
\hline & DNS-integritás & $\sqrt{ }$ & \\
\hline & Metiláció & $\sqrt{ }$ & $\sqrt{ }$ \\
\hline \multirow{5}{*}{$\begin{array}{l}\text { Hepatocellularis } \\
\text { carcinoma }\end{array}$} & Metiláció & $\sqrt{ }$ & $\sqrt{ }$ \\
\hline & $\begin{array}{l}\text { Mikroszatellita- } \\
\text { eltérés }\end{array}$ & & $\sqrt{ }$ \\
\hline & Mutáció & $\sqrt{ }$ & $\sqrt{ }$ \\
\hline & DNS-integritás & $\sqrt{ }$ & $\sqrt{ }$ \\
\hline & Vírus-DNS & $\sqrt{ }$ & \\
\hline \multirow[t]{3}{*}{ Húgyhólyag } & DNS-integritás & $\sqrt{ }$ & $\sqrt{ }$ \\
\hline & Metiláció & $\sqrt{ }$ & \\
\hline & $\begin{array}{l}\text { Mikroszatellita- } \\
\text { eltérés }\end{array}$ & $\sqrt{ }$ & \\
\hline \multirow[t]{5}{*}{ Mell } & Metiláció & $\sqrt{ }$ & $\sqrt{ }$ \\
\hline & $\begin{array}{l}\text { Mikroszatellita- } \\
\text { eltérés }\end{array}$ & $\sqrt{ }$ & $\sqrt{ }$ \\
\hline & DNS-integritás & & $\sqrt{ }$ \\
\hline & Mutáció & & $\sqrt{ }$ \\
\hline & Mitokondrium & $\sqrt{ }$ & \\
\hline \multirow[t]{3}{*}{ Petefészek } & Metiláció & $\sqrt{ }$ & $\sqrt{ }$ \\
\hline & DNS-integritás & $\sqrt{ }$ & \\
\hline & Mutáció & & $\sqrt{ }$ \\
\hline \multirow[t]{4}{*}{ Prosztata } & Metiláció & $\sqrt{ }$ & $\sqrt{ }$ \\
\hline & $\begin{array}{l}\text { Mikroszatellita- } \\
\text { eltérés }\end{array}$ & $\sqrt{ }$ & \\
\hline & DNS-integritás & $\sqrt{ }$ & $\sqrt{ }$ \\
\hline & Mitokondrium & & $\sqrt{ }$ \\
\hline
\end{tabular}

vényesül. Egy sor további lncRNA-ról igazolódott, hogy különböző jelátviteli utakon keresztül vesznek részt a petefészekrákos sejtek proliferációjának, migrációjának, inváziójának, áttétképzésének és kemoterápiával szembeni érzékenységének szabályozásában [50].

Dahiya és mtsai 2008-as tanulmányukban 56 különböző miRNS szerepét igazolták a petefészekrák patogenezisében, s közülük 16 mutatott átfedést más tanulmányokban már feltételezett jelentőségükkel. A 16 miRNS közül 9-nél a kontrollhoz képest csökkent expresszió (let-7d, miR-106b, miR-122a, miR-141, miR-183, miR195, miR-200a, miR-335, mir424), 7-nél pedig megnövekedett expresszió (miR-100, miR-199a, miR-296, 
miR-29a, miR-29c, miR-99a, mir-494) volt a jellemző [54]. A let-7 miRNS-család olyan konzekvens változásai jellemzőek petefészekrákban, amelyek szuppresszor funkcióra utalnak [48]. Bár a miR-21 túlexpresszióját számos daganattípusban kimutatták, petefészekrákban ez a típus bizonyult a legkifejezettebben alulreguláltnak. Nem meglepő, hogy a miR-2l az apoptózissal és a csökkent sejtproliferációval asszociált miRNS-marker. A $m i R-221$ és miR-222 a CDKNIC-expresszió befolyásolása révén játszik szerepet a petefészekrák patogenezisében [55]. Klinikai vizsgálatok szerint a kettő aránya szignifikáns korrelációt mutat a túléléssel. A 3,7 alatti expressziós arányú esetek medián túlélése 35 hónap alatti, míg a 3,7 fölötti expressziós arányú esetek medián túlélése 35 hónap fölötti volt. A miR-152 expressziója petefészekrákos sejtekben lényegesen alacsonyabb, mint a normálsejtekben. A miR-122-t korábban már tumorszuppresszorként jellemezték, ami emlőrákban az IGFIF-et célozva szabályozza a PI3K/Akt/mTOR/ p70S6K jelátviteli útvonal múködését. Langhe és mtsai tanulmánya petefészekrákban is hasonló funkciót igazolt a $m i R-122$ szintjei alapján [55].

\section{Prognosztika és onkoterápia}

A miR-152 magas expressziója petefészekrákban a cisplatinnal szembeni érzékenységgel jó korrelációt mutat [55]. Ennek a felismerésnek a jelentőségét az okozza, hogy bár a többnyire előrehaladott stádiumban felismert petefészekrák gyógyulási eredményeiben gyökeres változást hozott a mútéti technológia és az első vonalbeli platina-taxán kombinációs terápia, a betegek túlélését ma már jelentős részben a platinarezisztencia kialakulása korlátozza. A petefészekrák gyógyulási eredményeinek javításában prioritást élvez a platinarezisztens folyamatok ellen irányuló hatékony modalitások kifejlesztése. Számos új kemoterápiás, immunterápiás és célzott biológiai kezelési módszer kifejlesztése van folyamatban, de a platinaérzékenység előrejelzése továbbra sem megoldott. A tumormarker és képalkotó vizsgálatok csak egy-két hónap vagy néhány hónap elteltével képesek a platinarezisztencia kialakulásának igazolására. A miR-93 magas szintje szintén platinarezisztenciával hozható összefüggésbe. A $m i R-214$ a $m i R-93$-mal azonos útvonalon hat $[56,57]$. Yu és mtsai kimutatták, hogy a miR-29(a/b/c) csökkent expressziója cisplatinrezisztenciát jelez, és kísérletes körülmények között $m i R-29$ knock-out alkalmazásával a platinaérzékenység visszaállítható [58]. A szekvenciaanalízis technológiai fejlődése a teljes humán genom feltérképezésével 2001-ben megnyitotta az utat a széles palettával végzett genomasszociációs klinikai vizsgálatok előtt [59]. 2010-re már több száz olyan közlemény jelent meg, amelyek 70-50-30 génre tudták szúkíteni azokat a mintázatokat, amelyek egyes daganattípusokra vonatkozó fogékonyságot, egyes altípusok jelenlétét vagy kedvező és kedvezőtlen prognózis előrejel- zésében alkalmazhatónak bizonyultak. Petefészekrákkal kapcsolatban több száz beteg klinikai és egyenként mintegy 1000 különböző miRNS-expressziójára vonatkozó adataiból robusztus számítástechnikai elemzéssel sikerült egy 35 egyedi miRNS-re vonatkozó mintázatot kialakítani, amelyből egyszerû algoritmussal klinikailag releváns prognosztikai index határozható meg [60]. Az algoritmust egy szintén több száz klinikai esetet tartalmazó adatbázison validálva a szerzők meggyőzően igazolták az alacsony és magas rizikójú $(\mathrm{HR}>3)$ esetek elkülönítésének lehetőségét a miRNS-mintázat alapján.

\section{Következtetések}

A „szabad” nukleinsavak felhasználása az elkövetkező időszakban nemcsak a noninvazív praenatalis, hanem a „folyadékbiopszián” alapuló diagnosztikában is jelentősen növekedni fog. Folyik a biológiai szerepük pontos meghatározása és a különböző betegségek differenciáldiagnosztikájában való alkalmazhatóságuk vizsgálata. Az NIPT elterjedése várhatóan kiszorítja a méhlepénybiopsziát és a magzatvízvételt, amint lesz annyi klinikai adat, hogy a klinikai alkalmazhatóság és hasznosság pontosan meghatározható lesz.

A szív- és keringési betegségek diagnosztikájában, valamint az egyes kezelések várható hatékonyságának az előrejelzésével kapcsolatban sok közlemény jelenik meg, de jelenleg a klinikai gyakorlatban még nem alkalmazzák a „szabad" nukleinsavakon alapuló meghatározásokat, de néhány éven belül itt is komoly áttörés várható.

Az onkológiai betegségek diagnosztizálása lesz valószínúleg a következő terület, amely a magzati diagnosztika után a legnagyobb mértékben használja majd fel a „szabad” nukleinsavakat. Várható olyan új generációs gyógyszerek bevezetése, amelyek az interferenciát kihasználva új típusú gyógyszerek kifejlesztését teszik lehetővé.

Anyagi támogatás: A közlemény megírása anyagi támogatásban nem részesült.

Szerzői munkamegosztás: A szerzők a kézirat elkészítésében egyenlő arányban vettek részt. A cikk végleges változatát mindegyik szerző elolvasta és jóváhagyta.

Érdekeltség: A szerzőknek nincsenek érdekeltségeik.

\section{Irodalom}

[1] Mandel, P., Metais, P.: Les acides nucléiques du plasma sanguin chez l'homme. C. R. Seances Soc. Biol. Fil., 1948, 142(3-4), 241-243.

[2] Tan, E. M., Schur, P. H., Carr, R. I., et al.: Deoxybonucleic acid (DNA) and antibodies to DNA in the serum of patients with systemic lupus erythematosus. J. Clin. Invest., 1966, 45(11), $1732-1740$. 
[3] Leon, S. A., Shapiro, B., Sklaroff, D. M., et al.: Free DNA in the serum of cancer patients and the effect of therapy. Cancer Res., 1977, 37(3), 646-650.

[4] Dennis Lo, Y. M., Corbetta, N., Chamberlain, P. F., et al.: Presence of fetal DNA in maternal plasma and serum. Lancet, 1997, 350(9076), 485-487.

[5] Bianchi, D. W., Flint, A. F., Pizzimenti, M. F., et al.: Isolation of fetal DNA from nucleated erythrocytes in maternal blood. Proc. Natl. Acad. Sci., U.S.A., 1990, 87(9), 3279-3283.

[6] Bianchi, D. W., Klinger, K. W., Vadnais, T. J., et al.: Development of model system to compare cell separation methods for the isolation of fetal cells from maternal blood. Prenat. Diagn., 1996, 16(4), 289-298.

[7] Palomaki, G. E., Kloza, E. M., Lambert-Messerlian, G. M., et al. DNA sequencing of maternal plasma to detect Down syndrome: an international clinical validation study. Genet. Med., 2011, 13(11), 913-920.

[8] Yaron, $\Upsilon$.: The implications of non-invasive prenatal testing failures: review of an under-discussed phenomenon. Prenat. Diagn., 2016, 36(5), 391-396.

[9] Morain, S., Greene, F. M., Mello, M. M.: A new era in non-invasive prenatal testing. N. Eng. J. Med., 2013, 369(6), 499-501.

[10] Dennis Lo, Y. M., Chan, L. Y., Lo, K. W., et al.: Quantitative analysis of cell-free Epstein-Barr virus DNA in plasma of patients with nasopharyngeal carcinoma. Cancer Res., 1999, 59(6), 1188-1191.

[11] Yung, T. K., Chan, K. C., Mok, T. S., et al.: Single molecule detection of epidermal growth factor receptor mutations in plasma by microfluidics digital PCR in non-small cell lung cancer patients. Clin. Cancer Res., 2009, 15(6), 2076-2084.

[12] McBride, D. J., Orpana, A. K., Sotiriou, C., et al.: Use of cancerspecific genomic rearrangements to quantify disease burden in plasma from patients with solid tumors. Genes Chromosomes Cancer, 2010, 49(11), 1062-1069.

[13] Go, A. T., van Vugt, J. M., Oudejans, C. B., et al.: Non-invasive aneuploidy detection using free fetal DNA and RNA in maternal plasma: recent progress and future possibilities. Hum. Reprod. Update, 2011, 17(3), 372-382.

[14] Orozco, A. F., Lewis, D. E.: Flow cytometric analysis of circulating microparticles in plasma. Cytometry A, 2010, 77(6), 502-514.

[15] Napoli, C., Lemieux, C., Jorgensen R.: Introduction of a chimeric chalcone synthase gene into petunia results in reversible co-suppression of homologous genes in trans. Plant Cell, 1990, 2(4), 279-289.

[16] Fire, A., Xu, S., Montgomery, M. K., et al.: Potent and specific genetic interference by double stranded RNA in Caenorbabditis elegans. Nature, 1998, 391(6669), 806-811.

[17] Weber, J. A., Baxter, D. H., Zhang, S., et al.: The microRNA spectrum of 12 body fluids. Clin. Chem., 2010, 56(11), 1733-1741

[18] Nagy, Z., Igaz, P.: Introduction to microRNAs: Biogenesis, action, relevance of tissue microRNAs in disease pathogenesis, diagnosis and therapy - The concept of circulating microRNAs. In: Igaz, P. (ed.): Circulating microRNAs in disease diagnostics and their potential biological relevance. Spinger, Basel, 2015, 4-30.

[19] Kosaka, N., Iguchi, H., Ochiya, T.: Circulating microRNA in body fluid: a new potential biomarker for cancer diagnosis and prognosis. Cancer Sci., 2010, 101(10), 2087-2092.

[20] Chan, K. C., Zhang, J., Hui, A. B., et al.: Size distributions of maternal and fetal DNA in maternal plasma. Clin. Chem., 2004, $50(1), 88-92$.

[21] Li, Y., Zimmermann, B., Rusterholz, C., et al.: Size separation of circulatory DNA in maternal plasma permits ready detection of fetal DNA polymorphisms. Clin. Chem., 2004, 50(6), 10021011

[22] Dennis Lo, Ү. M., Chan, K. C., Sun, H., et al.: Maternal plasma DNA sequencing reveals the genome-wide genetic and mutational profile of the fetus. Sci. Transl. Med., 2010, 2(61), 61ra91.
[23] Mouliere, F., Robert, B., Arnau Peyrotte, E., et al.: High fragmen tation characterizes tumour-derived circulating DNA. PLoS ONE, 2011, 6(9), e23418

[24] Ellinger, J., Wittkamp, V., Albers, P., et al.: Cell-free circulating DNA: diagnostic value in patients with testicular germ cell cancer. J. Urol., 2009, 181(1), 363-371.

[25] Jiang, P., Chan, M. W., Chan, K. C., et al.: Lengthening and shortening of plasma DNA in hepatocellular carcinoma patients. Proc. Natl. Acad. Sci. U.S.A., 2015, 112(11), E1317-E1325

[26] Zhu Y., Tian, F., Li, H., et al.: Profiling maternal plasma microRNA expression in early pregnancy to predict gestational diabetes mellitus. Int. J. Gyn. Obstet., 2015, 130(1), 49-53.

[27] Hromadnikova, I., Kotlabova, K., Hympanova, L., et al.: Gestational hypertension, preeclampsia and intrauterine growth restriction induce dysregulation of cardiovascular and cerebrovascular disease associated microRNAs in maternal whole peripheral blood. Thromb. Res., 2016, 137, 126-140.

[28] Zhu, S., Chao, L, Zhu, J., et al.: Identification of maternal serum microRNAs as novel non-invasive biomarkers for prenatal detection of fetal congenital heart defects. Clin. Chim. Acta, 2013, 424, 66-72.

[29] Ma, L., Bajic, B. V., Zhang, Z.: On the classification of long noncoding RNAs. RNA Biol., 2013, 10(6), 924-933.

[30] Des Andres-Pablo, A., Morillon, A., Wery, M.: LncRNAs, lost in translation or licence to regulate? Curr. Genet., 2016 May 26. DOI: 10.1007/s00294-016-0615-1. [Epub ahead of print]

[31] Bianchi, D. W., Platt, L. D., Goldberg, J. D., et al.: Genome-wide fetal aneuploidy detection by maternal plasma DNA sequencing. Obstet. Gynecol., 2012, 119(5), 890-901.

[32] Norton, M. E., Brar, H., Weiss, J., et al.: Non-Invasive Chromosomal Evaluation (NICE) Study: results of a multicenter prospective cohort study for detection of fetal trisomy 21 and trisomy 18. Am. J. Obstet. Gynecol., 2012, 207(2), 137el-137e8.

[33] Lench, N., Barrett, A., Fielding, S., et al.: The clinical implementation of non-invasive prenatal diagnosis for single gene disorders: challanges and progress made. Prenat. Diagn., 2013, 33(6), 555-562.

[34] Sayed, A. S., Xia, K., Yang, T.-L., et al.: Circulating microRNAs: A potential role in diagnosis and prognosis of acute myocardial infarction. Dis. Markers, 2013, 35(5), 561-566.

[35] Kukreja, R. C., Yin, C., Salloum, F. N.: MicroRNAs: new players in cardiac injury and protection. Mol. Pharmacol., 2011, 80(4), 558-564.

[36] Meder, B., Keller, A., Vogel, B., et al.: MicroRNA signatures in total peripherial blood as novel biomarkers for acute myocardial infarction. Basic Res. Cardiol, 2011, 106(1), 13-23.

[37] Wang, G. K., Zhu, J. Q., Zhang, J. T., et al.: Circulating microRNA: a novel potential biomarker for early diagnosis of acute myocardial infarction in humans. Eur. Heart J., 2010, 31(6), 659-666.

[38] Devaux, Y., Vausort, M., Goretti, E., et al.: Use of circulating microRNAs to diagnose acute myocardial infarction. Clin. Chem., $2012,58(3), 559-567$

[39] Watson, C. J., Gupta, S. K., O'Connell, E., et al.: MicroRNA signitures differentiate preserved from reduced ejection fraction heart failure. Eur. J. Heart Fail., 2015, 17(4), 405-415.

[40] Ponikowski., P., Voors, A. A., Anker, S. D., et al.: 2016 ESC Guidelines for the diagnosis and treatment of acute and chronic heart failure. The Task Force for the diagnosis and treatment of acute and chronic heart failure of the European Society of Cardiology (ESC) Developed with the special contribution of the Heart Failure Association (HFA) of the ESC. Eur. Heart J., 2016, 37(27), 2129-2200.

[41] Clemens, M., Szegedi, Z., Kardos, L., et al.: The Seattle Heart Failure Model predicts survival in patients with cardiac resynchronization therapy: a validation study. J. Card. Fail., 2012, 18(9), 682-687. 
[42] Melman, Y. F., Shah, R., Danielson, K., et al.: Circulating microRNA-30d is associated with response to cardiac resynchronization therapy in heart failure and regulates cardiomyocyte apoptosis: A translational pilot study. Circulation, 2015, 131(25), 2202-2216

[43] Liu, Z., Zhou, C., Liu, Y., et al.: The expression levels of plasma microRNAs in atrial fibrillation patients. PloS ONE, 2012, 7(9), e44906.

[44] McManus, D. D., Lin, H., Tanriverdi, K., et al.: Relations between circulating microRNAs and atrial fibrillation: data from the Framingham Offspring Study. Heart Rhythm, 2014, 11(4), 663-669.

[45] Klattenhoff, C. A., Schenermann, J. C., Surface, L. E., et al.: Braveheart, a long noncoding RNA required for cardiovascular lineage commitment. Cell, 2013, 152(3), 570-583.

[46] Grote, P., Wittler, L., Hendrix, D., et al.: The tissue-specific IncRNA Fendrr is an essential regulator of heart and body wall development in mouse. Dev. Cell, 2013, 24(2), 206-214.

[47] Kurian, L., Aguirre, A., Sancho-Martinez, I., et al.: Identification of novel long noncoding RNAs underlying vertebrate cardiovascular development. Circulation, 2015, 131(14), 1278-1290.

[48] Uchida, S., Dimmeler, S.: Long noncoding RNAs in cardiovascular disease. Circ. Res., 2015, 116(4), 737-750.

[49] Wang, K., Sun, T., Li, N., et al.: MDRL IncRNA regulates the processing of miR-484 primary transcript by targeting miR-361. PLoS Genet., 2014, 10(7), el004467.

[50] Zhong, Y., Gao, D., He, S., et al.: Dysregulated expression of long noncoding RNAs in ovarian cancer. Int. J. Gynecol. Cancer, 2016, 26(9), 1564-1570.

[51] Rangel, L. B., Sherman-Baust, C. A., Wernyj, R. P., et al.: Characterization of novel human ovarian cancer-specific transcripts (HOSTs) identified by serial analysis of gene expression. Oncogene, 2003, 22(46), 7225-7232.

[52] Gao, Y., Meng H., Liw, S., et al.: LncRNA-HOST2 regulates cell biological behaviors in epithelial ovarian cancer through a mech- anism involving microRNA let-7b. Hum. Mol. Genet., 2015, 24(3), 841-852.

[53] Grier, D. G., Thompson, A., Kwasniewska, A., et al.: The pathophysiology of $H O X$ genes and their role in cancer. J. Pathol., 2005, 205(2), 154-171.

[54] Dabiya, N., Sherman-Baust, C. A., Wang, T. L., et al.: MicroRNA expression and identification of putative miRNA targets in ovarian cancer. PLoS ONE, 2008, 3(6), e2436.

[55] Langhe, R., Norris, L., Saadeh, F. A., et al.: A novel serum microRNA panel to discriminate benign from malignant ovarian disease. Cancer Letters, 2015, 356(2), 628-636.

[56] Katz, B., Tropé, C. G., Reich, R., et al.: MicroRNAs in ovarian cancer. Hum. Pathol., 2015, 46(9), 1245-1256.

[57] Fu, X., Tian, J., Zhang, L., et al.: Involvement of microRNA-93, a new regulator of PTEN/Akt signaling pathway, in regulation of chemotherapeutic drug cisplatin chemosensitivity in ovarian cancer cells. FEBS Letters, 2012, 586(9), 1279-1286.

[58] Yu, P. N., Yan, M. D., Lai, H. C., et al.: Downregulation of miR29 contributes to cisplatin resistance of ovarian cancer cells. Int J. Cancer, 2014, 134(3), 542-551.

[59] Hartman, M., Loy, E. Y., Ku, C. S., et al.: Molecular epidemiology and its current clinical use in cancer management. Lancet Oncol., 2010, 11(4), 383-390.

[60] Bagnoli, M., Canevari, S., Califano, D., et al.: Development and validation of a microRNA-based signature (MiROvaR) to predict early relapse or progression of epithelial ovarian cancer: a cohort study. Lancet Oncol., 2016, 17(8), 1137-1146.

(Nagy Bálint dr., Debrecen, Nagyerdei krt. 98., 4032 e-mail: nagy.balint@med.unideb.hu)

\section{XVIII. kerületben EGYNAPOS SEBÉSZET kiadó}

A közel negyed évszázada sikeresen müködő ORMOS Intézet újonnan kialakított, mintegy $300 \mathrm{~m}^{2}$-es egynapos sebészeti részlege részben vagy teljes egészében (nagyon kedvező feltételekkel) bérbe vehető, akár egy óra időtartamra is.

A rendelő ÁNTSZ engedéllyel rendelkezik. Tömegközlekedéssel és autóval is könnyen megközelíthető, ingyenes parkolási lehetőség az utcán megoldott.
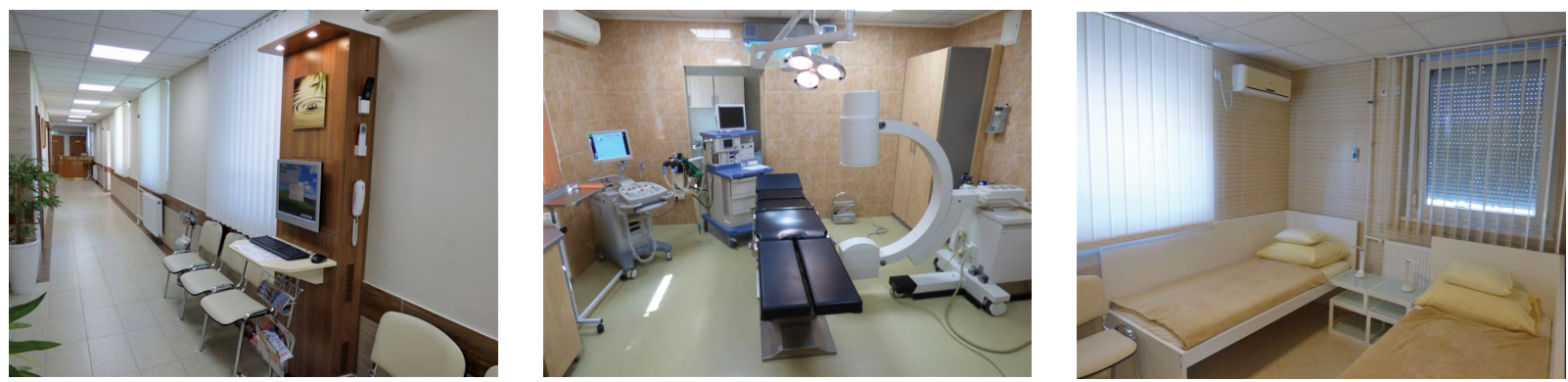

Érdeklődés esetén bővebb információért kérem, forduljon Parádi lldikó ügyvezető igazgatóhoz. Tel.: +36 205551680 